\title{
Selective DNA Adsorption on Layered Double Hydroxide Nanoparticles
}

\author{
Kyoung-Min Kim, Chung-Berm Park, ${ }^{\dagger}$ Ae-Jin Choi, ${ }^{\dagger}$ Jin-Ho Choy, ${ }^{\ddagger}, *$ and Jae-Min Oh* \\ Department of Chemistry and Medical Chemistry, College of Science and Technology, Yonsei University, \\ Wonju, Gangwondo 220-710,Korea. E-mail: jaemin.oh@yonsei.ac.kr \\ ${ }^{\dagger}$ National Institute of Horticultural \& Herbal Science (NIHHS) of RDA, Eumseonggun, Chungcheongbukdo 369-873, Korea \\ *Center for Intelligent Nano Bio Materials (CINBM), Department of Bio Inspired Science and Department of Chemistry and \\ Nano Science, Ewha Womans University, Seoul 120-750,Korea.*E-mail: jhchoy@ewha.ac.kr
} Received April 6, 2011, Accepted May 13, 2011

\begin{abstract}
We investigated the selective deoxyribonucleic acid (DNA) adsorption on layered double hydroxide (LDH) nanoparticles via studying the interaction between positively charged LDH nanoparticle as adsorbent and negatively charged adsorbates such as methyl orange (MO), fluorescein (FL), and DNA strands. The size controlled LDH $\left(\mathrm{Mg}_{0.78} \mathrm{Al}_{0.22}(\mathrm{OH})_{2}\left(\mathrm{CO}_{3}\right)_{0.11} \cdot m \mathrm{H}_{2} \mathrm{O}\right)$ was prepared by conventional coprecipitation method, followed by the hydrothermal treatment. According to the adsorption isotherms, the adsorbed amounts of MO and FL were similar, however, that of DNA were much larger. The adsorption behaviors were well fitted to Freundlich adsorption model. The concentration dependent adsorption behavior on LDH surface was described in order to verify the selective DNA separation ability. The result showed that the LDH has advantages in selective adsorption of DNA competing with single molecular anions.
\end{abstract}

Key Words : Layered double hydroxide, Deoxyribonucleic acid, Adsorption, Separation

\section{Introduction}

Recently, DNA separations and gatherings are attracting tremendous attentions in biotechnologies and forensic sciences. ${ }^{1-5}$ In biotechnologies, DNA is selectively separated from cells or tissues in order to verify the genetic disorder or to modify the genetic information. ${ }^{1,2,4}$ More specifically, gathering trace amount of DNA from bloodstain or separating artificially encoded DNA strands plays an important role to solve cases in forensic science. ${ }^{3,5}$ Numerous inorganic adsorption systems including silica, metal oxide, and hydroxide are extensively studied and some of them are already commercialized. ${ }^{6}$ Among those inorganic adsorbents, layered double hydroxide (LDH) nanoparticles, which are also called anionic nanoclay, ${ }^{7,8}$ are considered as potent DNA collection material as they have tunable physicochemical properties like surface area, particle size, and charge density as well as biocompatibility. ${ }^{9}, 10$

The general formula of LDH is $\left[\mathrm{M}(\mathrm{II})_{1-\mathrm{x}} \mathrm{M}(\mathrm{III})_{\mathrm{x}}(\mathrm{OH})_{2}\right]^{\mathrm{x}}$ $\left(\mathrm{A}^{\mathrm{n}-}\right)_{\mathrm{x} / \mathrm{n} \cdot} \cdot m \mathrm{H}_{2} \mathrm{O}$, where $\mathrm{M}(\mathrm{II})$ and $\mathrm{M}(\mathrm{III})$ are divalent and trivalent metals and, $\mathrm{A}^{\mathrm{n}-}$ stands for anion species. ${ }^{11}$ The edge sharing array of $\mathrm{M}(\mathrm{II})(\mathrm{OH})_{6}$ octahedrons make 2-dimensional sheets and the isomorphic substitution of M(II) with $\mathrm{M}(\mathrm{III})$ produces permanent positive charge which is compensated by the interlayer anions through electrostatic interaction. Due to their positive zeta potential $(\sim+40 \mathrm{mV}$ of $\xi$ potential $)$ and specific surface charge density $\left(1 \times 10^{20} \sim 5 \times\right.$ $10^{20} \mathrm{e}^{-} / \mathrm{g}$ ), LDHs have already been studied as scavengers of hazardous substances with negative charge in aqueous environments. ${ }^{12}$ Their controllable particle size (from tens of nanometers to a few micrometers) and flexible metal composition make it possible to utilize them in various appli- cations such as biological and environmental system. ${ }^{13}$

Although LDHs have a variety of advantages as bio- and eco-friendly anionic adsorption system, as far as we know, there have been few researches on the adsorption behavior of LDHs with various types of anionic molecules. It is expected that the molecular shape and charge density of adsorbate anions affects on both adsorption kinetics and thermodynamics. In this report, we are going to describe the concentration dependent adsorption behavior of various kinds of anionic molecules on LDH surface in order to verify the DNA separation ability of LDH nanoparticles.

\section{Experimental}

Reagents. Magnesium nitrate hexahydrate $\left(\mathrm{Mg}\left(\mathrm{NO}_{3}\right)_{2} \cdot 6 \mathrm{H}_{2} \mathrm{O}\right)$, aluminum nitrate nonahydrate $\left(\mathrm{Al}\left(\mathrm{NO}_{3}\right)_{3} \cdot 9 \mathrm{H}_{2} \mathrm{O}\right)$, sodium bicarbonate $\left(\mathrm{NaHCO}_{3}\right)$, methyl orange $\left(\mathrm{C}_{14} \mathrm{H}_{14} \mathrm{~N}_{3} \mathrm{NaO}_{3} \mathrm{~S}\right)$, fluorescein $\left(\mathrm{C}_{20} \mathrm{H}_{12} \mathrm{O}_{5}\right)$, deoxyribonucleic acid sodium salt (Type XIV: From Herring Testes), chloroform:isoamyl alcohol (24:1), and phenol solution were purchased from Aldrich. Sodium hydroxide pellets $(\mathrm{NaOH})$ were supplied by Daejung Chemicals \& Metals Co., Ltd.

Preparation LDH Nanoparticle. The LDH nanoparticle $\left(\mathrm{Mg}_{0.78} \mathrm{Al}_{0.22}(\mathrm{OH})_{2}\left(\mathrm{CO}_{3}\right)_{0.11} \cdot m \mathrm{H}_{2} \mathrm{O}\right)$ was prepared by conventional coprecipitation. ${ }^{10}$ Typically, alkaline solution (0.9 $\mathrm{M} \mathrm{NaOH} / 0.675 \mathrm{M} \mathrm{NaHCO}_{3}$ ) was added dropwisely to a mixed metal solution $\left(0.3 \mathrm{M} \mathrm{Mg}^{2+} / 0.15 \mathrm{M} \mathrm{Al}^{3+}\right)$ until $\mathrm{pH}$ $\sim 9.5$. The mixture was hydrothermally treated at $373 \mathrm{~K}$ for $48 \mathrm{hrs}$ to obtain size controlled LDH nanoparticles. The white precipitate was centrifuged, repeatedly washed with deionized water and then freeze-dried.

Powder X-ray diffraction pattern was recorded by a (XRD; 
Rigaku D/Max-2000/PC) diffractometer with Ni-filtered $\mathrm{Cu}-\mathrm{K} \alpha$ radiation $(\lambda=1.5418 \AA)$. The fourrier transform infrared (FT-IR) spectrum for LDH was obtained by Perkin Elmer spectrum one FT-IR spectrometer using $\mathrm{KBr}$ pellet method. The morphology and particle size of the prepared LDH were investigated by scanning (SEM; JEOL JSM6700F) and transmission electron microscopy (TEM; JEOL JEM 1010). The chemical composition of the LDH was analyzed by inductively coupled plasma-atomic emission spectroscopy (ICP-AES; PerkinElmer/Optima-4300 DV).

Purification of Adsorbates. MO and FL were used without further purification. Type XIV crude DNA was purified through conventional phenol extraction method. ${ }^{14}$ The extraction solution containing phenol solution, chloroform, and isoamyl alcohol with 25:24:1 ratio was well mixed with aqueous DNA solution $(2 \mathrm{mg} / \mathrm{mL})$ and then centrifuged at 4,000 rpm for $15 \mathrm{~min}$. The supernatant was collected and the same process was repeated 4 times. The final supernatant was mixed twice volume of ethanol and a small amount of $\mathrm{NaCl}$ for $30 \mathrm{~min}$ in $268 \mathrm{~K}$ refrigerator. Thus obtained recrystallized DNA precipitate was centrifuged, repeatedly washed with ethanol.

Adsorption Study. Powdered LDH was dispersed in deionized water $(0.25 \mathrm{mg} / \mathrm{mL})$ and $1 \mathrm{~mL}$ of the suspension was added to $10 \mathrm{~mL}$ of each adsorbate solution such as MO, FL, and DNA solution with various concentrations from $1.93 \times 10^{-6}$ to $1.60 \times 10^{-4} \mathrm{M}$. The mixture was gently shaken at room temperature for $24 \mathrm{~h}$ and then centrifuged at 12,000 rpm for $10 \mathrm{~min}$ in order to separate supernatant.

The adsorbed amount was determined by UV spectrometer (SHIMADZU/UV-1800) at the wavelength of 464, 233, and $260 \mathrm{~nm}$ for MO, FL, and DNA, respectively.

\section{Results and Discussion}

Characterization of LDH. According to the X-ray diffr- (a)

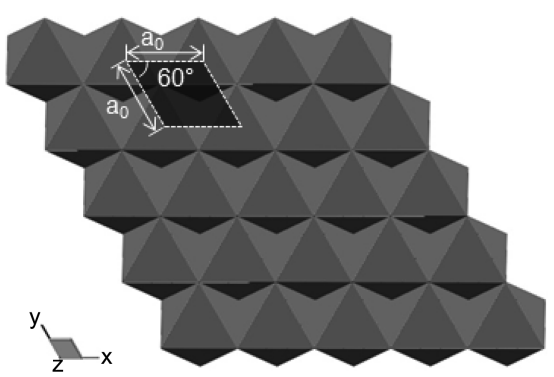

(b)

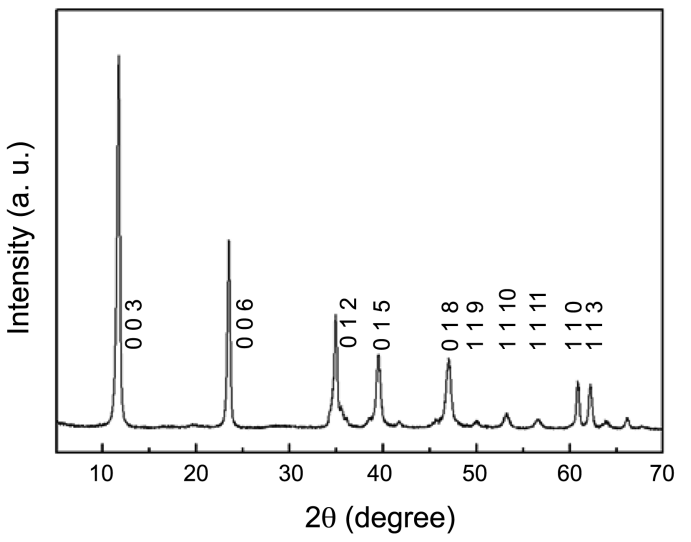

(d)

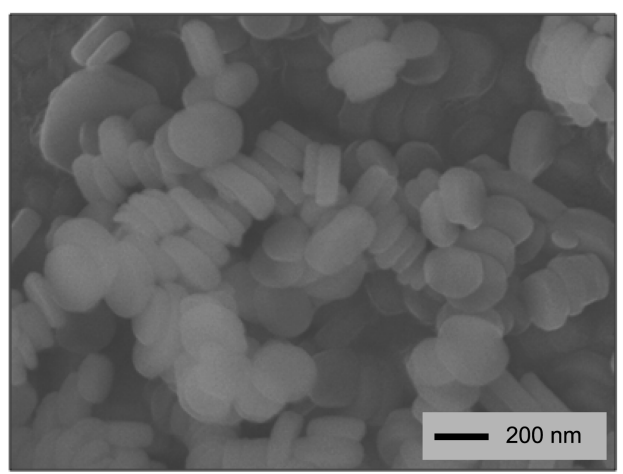

Equivalent surface area of $\mathrm{LDH}\left[\left(\mathrm{Mg}_{0.78} \mathrm{Al}_{0.22}(\mathrm{OH})_{2}\right)^{0.22+}\right]$ per unit charge

$a_{0}=3.04 \AA$, Area of the parallelogram $=a_{0}{ }^{2} x \sin 60^{\circ}=8.0 \AA^{2}$ charge evolution in the parallelogram: $\left[\mathrm{Mg}_{0.78} \mathrm{Al}_{0.22}\left(\mathrm{OH}_{2}\right)\right]^{0.22+}$ equivalent area per charge $=8.0 \AA^{2} /(0.22+)=36.4 \AA^{2} /(1+)$

(c)

(e)
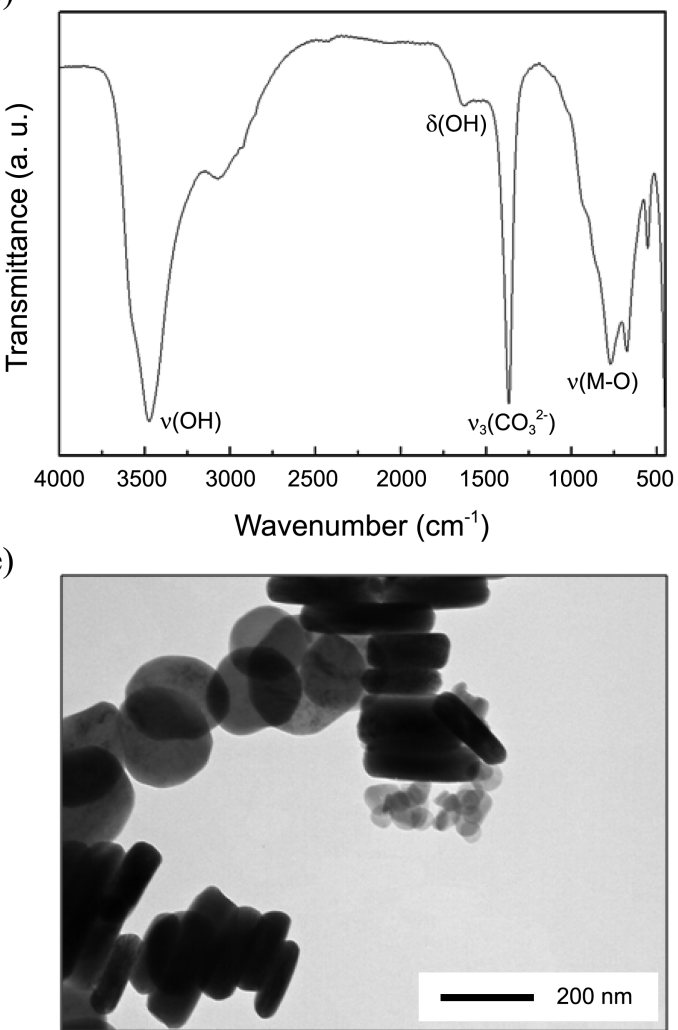

Figure 1. (a) The schematic structure of LDH (top-view) and the equivalent surface area of LDH per unit charge $\left(\AA^{2} /(+)\right)$, (b) X-ray diffraction pattern, (c) fourrier transform infrared spectrum, (d) the scanning electron microscopic image, and (e) the transmission electron microscopic image of size controlled LDH. 
Table 1. Chemical formula and the surface area of LDH per unit charge

\begin{tabular}{ccc}
\hline Chemical formula $^{a}$ & $\begin{array}{c}\text { Cell parameter } \\
(\AA)\end{array}$ & $\begin{array}{c}\text { Equivalent surface area of } \\
\text { LDH per charge }\left(\AA^{2} /(+)\right)\end{array}$ \\
\hline $\mathrm{Mg}_{0.78} \mathrm{Al}_{0.22}(\mathrm{OH})_{2}$ & $\mathrm{a}_{0}=3.04$ & 36.4 \\
$\left(\mathrm{CO}_{3}\right)_{0.22}$ & $\mathrm{c}_{0}=22.74$ & \\
\hline
\end{tabular}

${ }^{a}$ Determined by inductively coupled plasma atomic emission spectroscopy (ICP-AES). ${ }^{b}$ Obtained from X-ray diffraction (XRD).

action patterns shown in Figure 1(b), the prepared LDH turned out to be well crystallized with interlayer carbonate ion having hexagonal cell parameters of $\mathrm{a}_{0}=3.04$ and $\mathrm{c}_{0}=$ $22.74 \AA$ of which results are in good accordance with the previously reported $\mathrm{LDH}^{15,16}$ (Table 1). As shown in Figure 1(c), the FT-IR spectrum exhibits all the characteristic stretching vibrations of LDHs. Peaks at 3400 and $800 \mathrm{~cm}^{-1}$ are attributed to the $v(\mathrm{OH})$ and $v(\mathrm{M}-\mathrm{O})$ in the metal hydroxide layers whereas those at 1630 and $1370 \mathrm{~cm}^{-1}$ are explained by the $\delta(\mathrm{OH})$ and $v_{3}\left(\mathrm{CO}_{3}{ }^{2-}\right)$ modes of interlayer water molecules and carbonate ions, respectively. ${ }^{11}$

The chemical composition of the LDH was determined to be $\mathrm{Mg}_{0.78} \mathrm{Al}_{0.22}(\mathrm{OH})_{2}\left(\mathrm{CO}_{3}\right)_{0.11} \cdot m \mathrm{H}_{2} \mathrm{O}$ by the ICP-AES (Table 1). The equivalent surface area of LDH per unit charge can be calculated to $36.4 \AA^{2} /(1+)$ as described in Figure 1(a). The SEM and TEM images of LDH shown in Figure 1(d) and (e) revealed that the nanoparticles have primary particle size of $\sim 200 \pm 20 \mathrm{~nm}$ with circular-lamellar morphology.

Adsorption Study. The adsorbed amount $(Q)$ of MO, FL, and DNA were plotted versus initial adsorbate concentration $\left(C_{i}\right)$. The adsorbed amount per gram $\mathrm{LDH}(Q)$ was calculated as follows; $Q(\mathrm{~mol} / \mathrm{g})=\left\{\left(C_{i}-C_{e}\right) \times V\right\} / m$, where $C_{i}$, $C_{e}$, and $m$ stand for the initial concentration, equilibrium concentration, and the mass of LDH adsorbent, respectively. ${ }^{17}$ As shown in Figure 2(a) and (b), regardless of adsorbate type, the adsorbed amount increases depending on the initial concentration. It is worthy to note here that the DNA adsorption on LDH is approximately twice compared to MO or FL, while the adsorbed amounts of $\mathrm{MO}$ and $\mathrm{FL}$ are similar. In other words, the adsorption of DNA on the LDH is significantly higher than single molecular adsorbates. In order to explain the difference in adsorption behavior in detail, the isotherms were fitted to well known adsorption models such as Freundlich, Langmuir, and the linear kinetics.

The Freundlich equation is represented as $Q=k \cdot C_{i}^{1 / n}(Q$ : adsorbed amount in $\mu \mathrm{g} / \mathrm{g}$ unit, $k$ : the adsorption coefficient $\left(k=k_{\text {adsorption }} / k_{\text {desorption }}\right)$, and $n$ : a correlation coefficient indicating the adsorption behavior). ${ }^{17}$ Langmuir equation is $C_{i} / Q$ $=1 / q_{m} \cdot k+C_{i} / q_{m}$ where $q_{m}$ and $k$ are adsorption coefficients. Linear model is simply expressed as $Q=K \cdot C_{i}$. For the linear regression, the Freundlich equation was modified to $\log Q=$ $1 / n \cdot \log C_{i}+\log k$. As shown in Table 2, the isotherms are best understood with Freundlich model having $R^{2}>0.99$ therefore we analyzed the adsorption behavior with Freundlich kinetics.

The correlation coefficients are displayed in Table 3 showing $k$ values of 627, 217, and 22 and $n$ values of 1.07, 0.90,
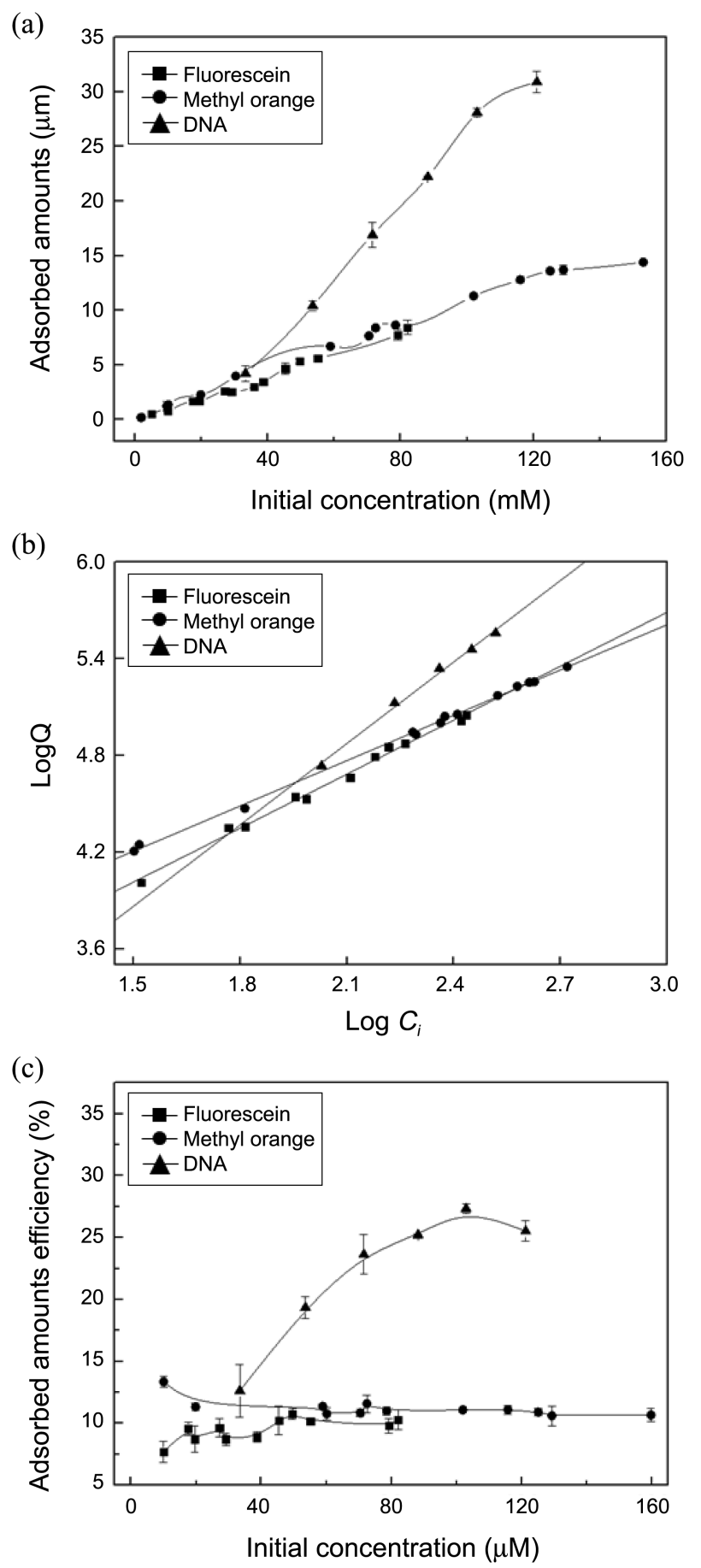

Figure 2. (a) The adsorption isotherms, (b) fiiting results according to Freundlich model, and (c) the adsorption efficiency of MO, FL, and DNA.

and 0.59 for MO, FL, and DNA, respectively. The significantly different correlation coefficients result from the different shape and charge density of each adsorbate.

Methyl orange and fluorescein exist as single molecule with characteristic shapes and anionic functional groups; $\mathrm{MO}$ has cylindrical shape with sulfonate $\left(-\mathrm{SO}_{3}^{-}\right)$group while FL has spherical shape with carboxylate $\left(-\mathrm{CO}_{2}^{-}\right)$ group (Fig. 3(a) and (b)). In contrast, DNA strands are biopolymers having helical structure and phosphate $\left(-\mathrm{PO}_{3}{ }^{-}\right)$ 
Table 2. The correlation coefficients and regression equation of isotherm models such as Freundlich, linear, and Langmuir

\begin{tabular}{lllc}
\hline Adsorbate & Isotherm models & Regression equation & $R^{2}$ \\
\hline Methyl orange & Freundlich & $y=0.938 \cdot x+2.797$ & 0.999 \\
& Linear & $y=435.45 \cdot x$ & 0.997 \\
\multirow{4}{*}{ Fluorescein } & Langmuir & $y=7 \times 10^{-7} \cdot x+0.002$ & 0.575 \\
& Freundlich & $y=1.117 \cdot x+2.337$ & 0.993 \\
& Linear & $y=395.47 \cdot x$ & 0.984 \\
DNA & Langmuir & $y=-2 \times 10^{-6} \cdot x+0.003$ & 0.458 \\
& Freundlich & $y=1.685 \cdot x+1.334$ & 0.995 \\
& Linear & $y=996.88 \cdot x$ & 0.937 \\
& Langmuir & $y=9 \times 10^{-6} \cdot x-0.002$ & 0.229 \\
\hline
\end{tabular}

in the backbone (Fig. 3(c)). Typically, a base pair contains two negatively charged nucleotides which periodically repeat every $3.4 \AA$. The required area per charge of each anionic species can be calculated by assuming the simplest molecular shape described in Figure 3. The estimated values for the equivalent area per charge are 23.8, 95.0, and 34.0 $\AA^{2} / \mathrm{e}^{-}$for $\mathrm{MO}, \mathrm{FL}$, and DNA, respectively.

As the adsorption between LDH and anionic adsorbates

(a)

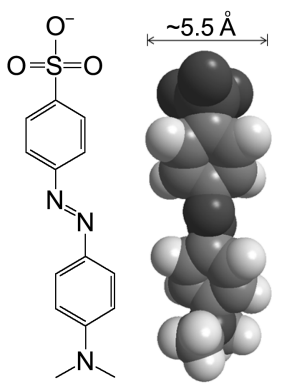

Equivalent surface area per unit charge of methyl orange molecule with sulfonate $\left(-\mathrm{SO}_{3}^{-}\right)$terminal. $(\sim 5.5 \AA / 2)^{2} x \pi \approx \sim 23.8 \AA^{2} / \mathrm{e}^{-}$

(b)

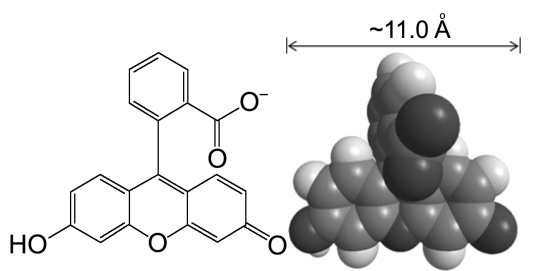

Equivalent surface area per unit charge of fluorescein molecule with carboxylate $\left(-\mathrm{CO}_{2}^{-}\right)$. $(\sim 11.0 \AA 2 / 2)^{2} x \pi \approx \sim 95.0 \AA^{2} / \mathrm{e}^{-}$

(c)

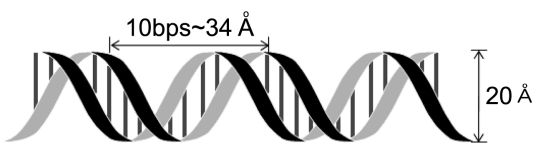

Equivalent surface area per unit charge of DNA strands. $1 \mathrm{bp}=2 \mathrm{e}^{-},(\sim 3.4 \AA) \times 20 \AA / 2 \mathrm{e}^{-} \approx \sim 34.0 \AA^{2} / \mathrm{e}^{-}$

Figure 3. Schematic structure and equivalent surface area per unit charge $\left(\AA^{2} / \mathrm{e}^{-}\right)$of anionic molecule adsorbates (a) MO, (b) FL, and (c) DNA strands were calculated.
Table 3. Adsorption coefficients obtained from Freundlich model

\begin{tabular}{lrcc}
\hline & $k$ & $n$ & $R^{2}$ \\
\hline Methyl orange & 627 & 1.07 & 0.999 \\
Fluorescein & 217 & 0.90 & 0.993 \\
DNA & 22 & 0.59 & 0.995 \\
\hline
\end{tabular}

are based on cation (LDH)-anion (adsorbate) interaction, the $k$ values are thought to be highly dependent on the equivalent area per unit charge. However, DNA shows much smaller $k$ value than expected. Smaller molecules like MO and FL move actively to adsorb on LDH and be stabilized. On the other hand, once adsorbed DNA can be also detached due to the physical strain of the dangling part, if only a small portion of strand is attached on the LDH surface.

As shown in Table 3, the $n$ values of MO and FL are 1.07 and 0.90 , respectively. Both $n$ values are approximately 1 , meaning that their adsorption behavior in Freundlich model is fairly similar to linear one (see the $R^{2}$ values in Table 2). The $n$ value of DNA is 0.59 with which we could expect the exponentially increasing adsorption with respect to the initial concentration. It means that the adsorbed amount of DNA strands rise rapidly according to the initial concentration increase since the polymeric DNA strands have more chance to interact with LDH surface than single molecules. Furthermore, LDH and DNA have similar equivalent area values per charge $\left(36.4 \AA^{2} /(+)\right.$ and $34.0 \AA^{2} /(-)$, respectively) exhibiting similar charge periodicity. This regularity in charge is thought to accelerate the adsorption of DNA on LDH surface.

It is also cross-confirmed by the adsorption efficiency estimation $^{18}$ (Fig. 2(c)). The adsorption efficiency $E$ is calculated as $E=\left(C_{e}-C_{i}\right) / C_{i} \times 100$. As shown in Figure 2(c), the efficiency of DNA adsorption increase dramatically (upto $25 \%$ ) upon $C_{i}$, while those of MO and FL are just fluctuating around $10 \%$. It is therefore concluded that the LDH has higher advantages in adsorbing DNA compared with single molecules. Even though the $k$ value for DNA is smaller than the single molecules, the final adsorption after equilibrium would be much higher.

\section{Conclusion}

In this report, we have investigated the adsorption behaviors of three kinds of anionic molecules such as MO, FL, and DNA strands on the size controlled LDH nanoparticles. It was revealed that the difference of adsorption amount among the adsorbates is mainly dependent on the area demand per unit charge $\left(\AA^{2} / \mathrm{e}^{-}\right)$for single molecules. In the case of DNA strands, adsorbed amount of DNA strands depended on initial concentration and exceeded single molecules due to the concurrence of equivalent area per charge and charge periodicity. We were successful to demonstrate that the LDH has advantage in selective adsorption of DNA competing with single molecular anions.

Acknowledgments. This work was supported by National 
Research Foundation of Korea Grant funded by the Korean Government (2010-0001488) and the Herbal Crop Research Project (PJ006921) of RDA, Republic of Korea and also by WCU (World Class University) program through the National Research Foundation of Korea funded by the Ministry of Education, Science and Technology (R33-2008-10082).

\section{Reference}

1. Choy, J.-H.; Oh, J.-M.; Park, M.; Sohn, K.-M.; Kim, J.-W. Adv. Mater. 2004, 16, 1181.

2. Lee, J. Y.; Kim, B.-K.; Seongpil, H.; Younghoon, L.; Juhyoun, K. Bull. Korean Chem. Soc. 2010, 31, 3099.

3. Park, D.-H.; Kim, J.-E.; Oh, J.-M.; Shul, Y.-G.; Choy, J.-H. J. Am. Chem. Soc. 2010, 132, 16735.

4. Jo, H.; Min, K.; Song, K.-m.; Ku, J. K.; Han, M. S.; Ban, C. Bull. Korean Chem. Soc. 2011, 32, 247.

5. Oh, J.-M.; Park, D.-H.; Choy, J.-H. Chem. Soc. Rev. 2011, 40, 583.

6. Choi, H. K.; Chang, J. H.; Ko, I. H.; Lee, J. H.; Jeong, B. Y.; Kim, J. H.; Kim, J. B. J Solid State Chem. 2011, 184, 805.

7. Lee, J. H.; Rhee, S. W.; Jung, D.-Y. Bull. Korean Chem. Soc.
2005, 26, 248.

8. Choy, J.-H.; Choi, S.-J.; Oh, J.-M.; Park, T. Appl. Clay Sci. 2007, $36,122$.

9. Pavan, P. C.; Crepaldi, E. L.; Valim, J. B. J. Colloid Interface Sci. 2000, 229, 346

10. Choi, S.-J.; Oh, J.-M.; Choy, J.-H. J. Inorg. Biochem. 2009, 103, 463.

11. Cavani, F.; Trifirò, F.; Vaccari, A. Catal. Today 1991, 11, 173.

12. Goh, K.-H.; Lim, T.-T.; Dong, Z. Water Res. 2008, 42, 1343.

13. Oh, J.-M.; Biswick, T. T.; Choy, J.-H. J. Mater. Chem. 2009, 19, 2553.

14. Sambrook, J.; Russell, D. W. Molecular Cloning: A Laboratory Manual, 3ed.; Cold spring harbor laboratory press: New York, 2001.

15. Costantino, U.; Coletti, N.; Nocchetti, M.; Aloisi, G. G.; Elisei, F.; Latterini, L. Langmuir 2000, 16, 10351.

16. Oh, J.-M.; Hwang, S.-H.; Choy, J.-H. Solid State Ionics 2002, 151, 285.

17. Shi, W.; Wei, M.; Jin, L.; Li, C. J. Mol. Catal. B-Enzym. 2007, 47, 58.

18. Park, D.-H.; Oh, J.-M.; Shul, Y.-G.; Choy, J.-H. J. Nanosci. Nanotech. 2008, $8,5014$. 